The final publication is available at Elsevier via https://dx.doi.org/10.1016/j.marpol.2018.08.018 @ 2018. This manuscript version is made available under the CC-BY-NC-ND 4.0 license https://creativecommons.org/licenses/by-nc-nd/4.0/

\title{
Human Dimensions of Ecosystem-Based Management: Lessons in Managing Trade-offs from the Northern Shrimp Fishery in Northern Peninsula, Newfoundland
}

Graham Epstein ${ }^{1 *}$, Evan Andrews ${ }^{1}$, Derek Armitage ${ }^{1}$, Paul Foley $^{2}$, Jeremy Pittman $^{3}$, Rebecca Brushett ${ }^{4}$

${ }^{1}$ Environmental Change and Governance Group. School of Environment, Resources and Sustainability, University of Waterloo, 200 University Avenue West, Waterloo, ON, N2L 3G1 Canada

${ }^{2}$ Environmental Policy Institute and Environmental Studies. School of Science and Environment Grenfell Campus, Memorial University 20 University Drive, Corner Brook, Newfoundland and Labrador, A2H 5G4 Canada

${ }^{3}$ School of Planning, University of Waterloo, 200 University Avenue West, Waterloo, ON, N2L 3G1, Canada

${ }^{4}$ Environmental Studies. School of Science and Environment Grenfell Campus, Memorial University 20 University Drive, Corner Brook, Newfoundland and Labrador, A2H 5G4 Canada

* Corresponding Author

\section{Abstract}

Fisheries can have significant impacts on the structure and functions of marine ecosystems, including impacts on habitats and non-target species. As a result, management agencies face growing calls to account for the ecosystem impacts of fishing, while navigating the political and economic interests of diverse stakeholders. This paper assesses the impacts of two specific factors on the attitudes and well-being of shrimp fishers in the context of a selective fisheries closure designed to protect crabs in the Northern Peninsula of Newfoundland and Labrador, Canada: (1) the species portfolios of fishers; and (2) democratic rulemaking. The results of this analysis suggest that shrimp fishers were more likely to support selective closures for the shrimp fishery if they also fished for crab, and felt they had an influence on the management of the fishery. The results further indicate that species portfolio diversification had a positive and statistically significant impact on the subjective economic well-being of fishers. This study contributes to an emerging literature on the human dimensions of ecosystem-based fisheries management, highlighting opportunities to address trade-offs in fisheries through species diversification and by enhancing the role and influence of fishers in management processes. 


\section{Introduction}

Fisheries managers are increasingly tasked with moving beyond conventional single-species management and towards an ecosystem-based approach to fisheries (Pikitch et al. 2004, Link 2010, Fogarty 2013, Long et al. 2015, Cormier et al. 2016). Ecosystem-based management is an approach that explicitly considers the interactions among the components of an ecosystem to address the cumulative impacts of human activities on the environment (Leslie and McLeod 2007). Consequently, ecosystem-based approaches tend to recommend the adoption of strategies to avoid or minimize the impacts of fishing on a diverse portfolio of ecosystem goods and services. These strategies can include controls on the exploitation of forage species to account for the needs of dependent predators (Rice and Duplisea 2014, Eddy et al. 2016, WWF 2016), rules to limit non-target mortality and bycatch (Pikitch et al. 2004, Phillips et al. 2010), and creation of marine protected areas to protect critical habitats (Kaiser et al. 2002, Link et al. 2011). However, progress has been slow (Pitcher et al. 2009) as broad support for the general notion of ecosystem-based management (Biedron and Knuth 2016, Long et al. 2016) masks opposition to specific policies such as marine protected areas, fisheries closures, and reductions in catch limits that give rise to trade-offs among different actors, activities or objectives (Browman et al. 2005, Bennett and Dearden 2014, Cavanagh et al. 2016). This paper therefore examines factors influencing stakeholder support for the inclusion of ecosystem considerations in fisheries by considering the impacts of species portfolios and democratic rulemaking on the attitudes of shrimp fishers towards a selective closure in the Northern Peninsula of Newfoundland and Labrador, Canada.

The sustainability of resources has long been understood to depend upon the ability of groups to develop strategies to address social dilemmas (Gordon 1954, Hardin 1968). Common-pool resources, such as fish, present challenges for human society because of a mismatch between public and private interests, generating incentives that promote excessive short-term exploitation at the expense of resource conditions and the long-term interests of fishers and society. These problems can be addressed by assigning secure and enforceable harvesting rights to individuals or groups, providing incentives for sustainable use and conservation of resources (Ostrom 1990, Pomeroy et al. 2001, Hilborn et al. 2005, Grafton et al. 2006, Costello et al. 2008, Branch 2009, Gutierrez et al. 2011, Pons et al. 2016). However, unlike the single resource context where actors primarily face trade-offs between short and long-term gains, ecosystem considerations tend to give rise to more significant trade-offs among different actors, activities and objectives (Leslie and McLeod 2007, Cheung and Sumaila 2008, Davies et al. 2018). Unfortunately, most research on ecosystem-based management has emphasized ecological and oceanographic aspects, providing limited guidance for addressing the social, economic and political dimensions of ecosystem-based management (Ommer et al. 2012).

Trade-offs refer to situations involving an asymmetric distribution of benefits and costs, often resulting from heterogenous preferences among actors for ecosystem goods and services (Hicks et al. 2013). Protected areas, for instance, appear to prioritize conservation interests at the expense of fishers (McShane et al. 2011), while selective fisheries closures and reductions in catch limits for lower trophic level species (i.e. forage fish) deliver benefits to sub-groups of fishers at the potential expense of other sub-groups (Mullowney et al. 2012, Rice and Duplisea 2014). Consequently, policies designed to address the ecosystem impacts of fishing tend to 
result in political trade-offs and conflicts, potentially undermining their adoption as key stakeholders organize to resist them and the overall legitimacy of the management system. Indeed, the politics of fisheries management is often highlighted as a key barrier for achieving sustainability in fisheries, as fishers and the politicians seeking their votes have sometimes exploited scientific uncertainties in pursuit of short-term economic and electoral returns (Botsford et al. 1997, Daw and Gray 2005). Absent the political will to address the ecosystem impacts of fishing, there is a need to better understand how stakeholders might come to support, or perhaps self-organize to demand the adoption of corresponding strategies. Section 1.1 provides a brief introduction to conflicts among northern shrimp (Pandalus borealis) and crab (Chionoecetes opilio) fishers in the Northern Peninsula of Newfoundland and Labrador, Canada, while section 1.2 continues by turning to theory to consider factors that might facilitate the management of ecosystem trade-offs in fisheries.

\subsection{Background on the Northern Shrimp Fishery}

Northern shrimp and crab fisheries became increasingly important to the resource-based economy of rural Newfoundland and Labrador with the collapse of more traditional groundfish stocks, which was accompanied by a rapid increase in the abundance of invertebrate species (Lilly et al. 2000). As a result, the Department of Fisheries and Oceans determined that shrimp were underexploited by the existing offshore shrimp fleet and initiated a process by which inshore operators affected by the groundfish closure could obtain a permit for shrimp.

Temporary permits were issued to affected fishers that chose to gear up for the shrimp fishery (i.e. acquired suitable vessels and gear) by a specified date, which were later converted to regular licenses (Foley et al. 2015). However, an expanding inshore shrimp fishery led to increased conflict with crab fishers who argued that shrimp trawling was having a variety of negative impacts on crab, including damage to habitats, leg loss, damaged carapaces and mortality (Dawe et al. 2007, DFO 2007, Kincaid and Rose 2014). As a result, the crab fishers successfully lobbied for a selective fisheries closure in the Hawke Channel, which prohibited trawling in a $1,370 \mathrm{~km}^{2}$ area of shrimp fishing area (SFA) 6 . This closure was later expanded to approximately $8800 \mathrm{~km}^{2}$ in 2004 and was joined by the approximately $7300 \mathrm{~km}^{2}$ Funk Island Deep closure in 2005, both of which are shown in Figure 1 below. 


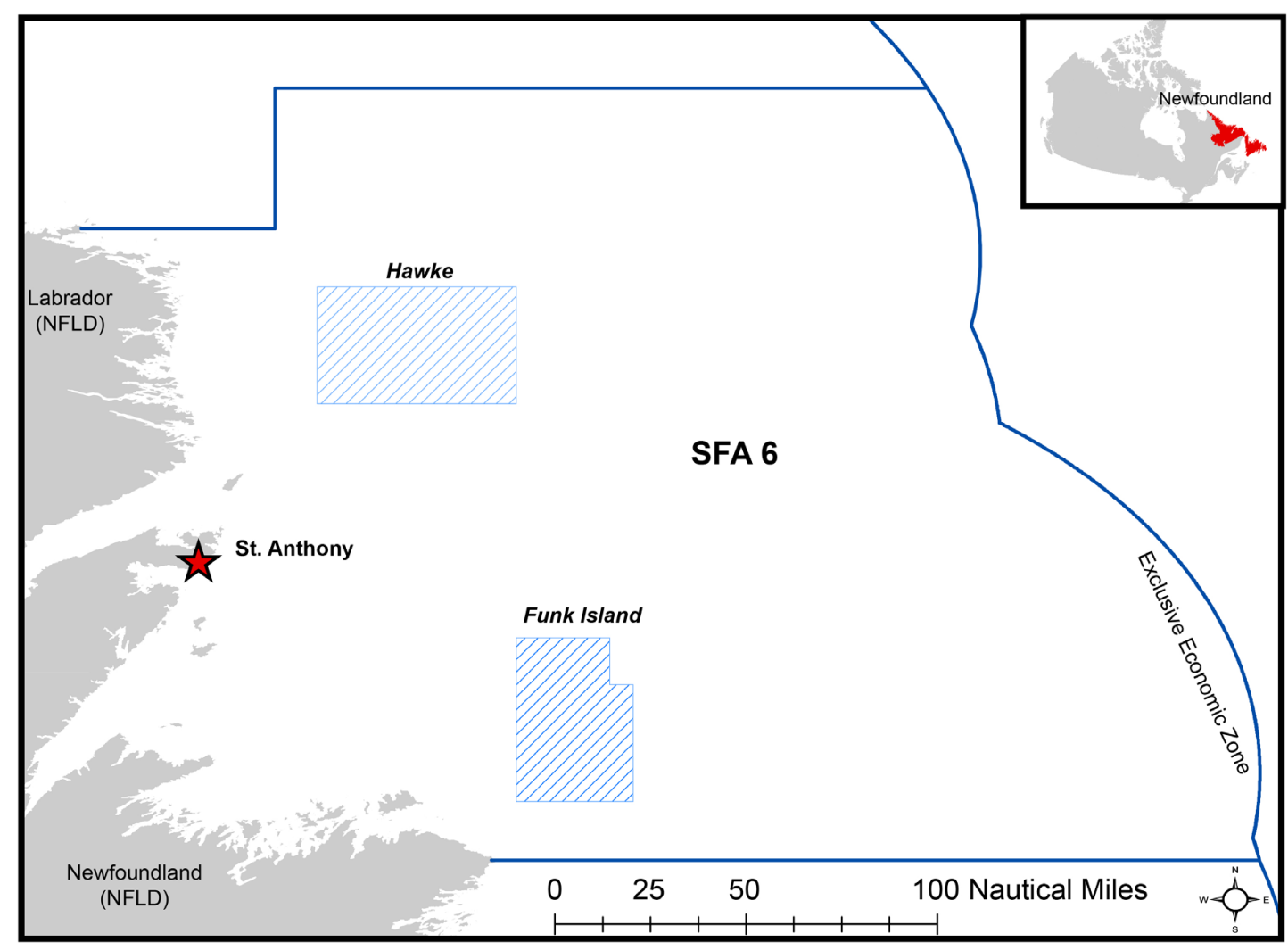

Figure 1: Map of closed areas and shrimp fishing area (SFA) 6. Star indicates location of field research.

The case of the selective closures for the shrimp fishery in Newfoundland provides a clear example that it is possible for stakeholders and governments to implement policies to address the ecosystem impacts of fishing (Kincaid and Rose 2014). It is worth noting that these closures were introduced during a period of relative abundance (Figure 2), potentially contributing to the lack of significant political conflict over their adoption. However, since then crab and shrimp stocks have been on the decline as part of a more general shift in the species composition of the North Atlantic ecosystem (Cheung et al. 2013, Mullowney et al. 2014, DFO 2016), and the shrimp fishery in particular has experienced a number of political conflicts over the allocation of fishing rights (Foley et al. 2013, Sprout et al. 2016, Foley and Mather 2018). Although the selective closures have played a relatively minor role in conflicts thus far; they provide no direct benefits to shrimp fishers, increase opportunity costs by displacing them from potential fishing grounds, and contribute to increased travel time and operational costs (Kincaid and Rose 2017). Whereas there is clear and ongoing support among local crab fishers to maintain these closures (Kincaid and Rose 2014), important questions remain regarding the perspectives of the shrimp fishers most affected by these closures. 


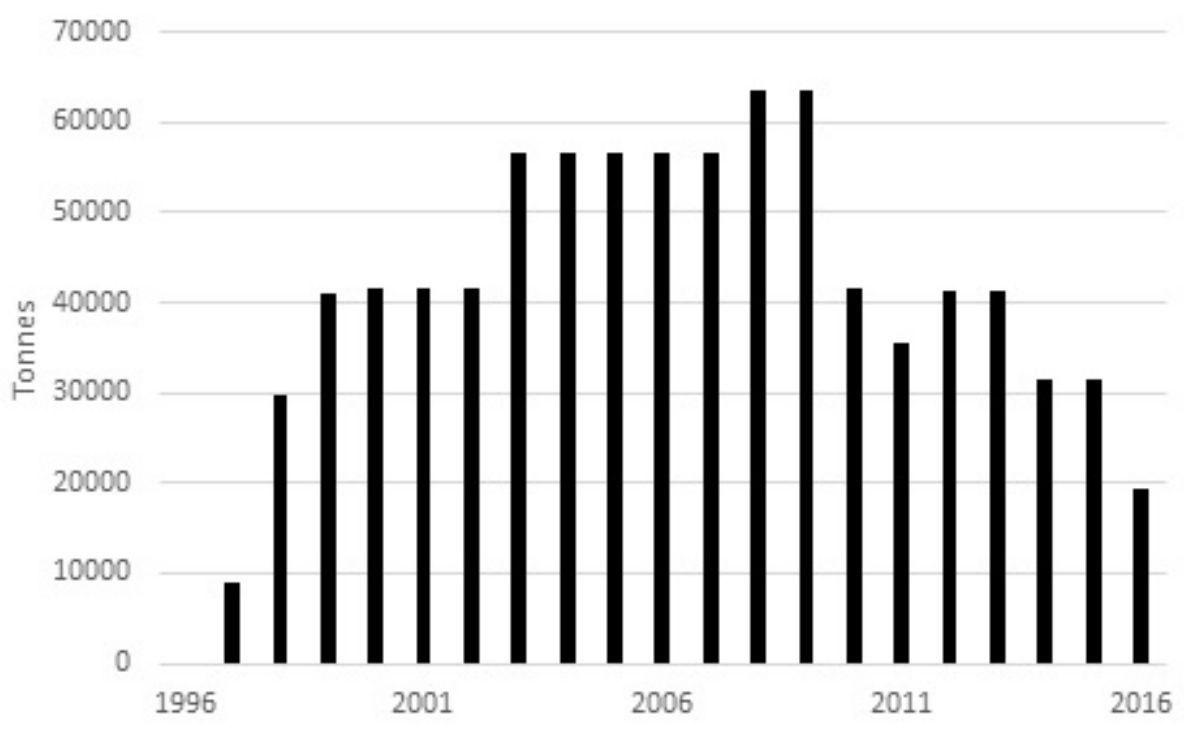

Figure 2: Inshore shrimp quotas in shrimp fishing area (SFA) 6. Source: Compiled by author from DFO (2007) and stock assessment reports (i.e. DFO 2016).

\subsection{Managing the ecosystem impacts of fisheries}

The ecosystem impacts of fishing are a classic example of an externality, wherein a mismatch between public and private interests result in costly impacts and outcomes for society (Buchanan and Stubblebine 1962, Martinet and Blanchard 2009). Externalities underlie a wide range of environmental problems including overexploitation of fisheries and other common-pool resources, pollution and climate change, and the broader impacts of human activities on natural ecosystems. Private actors are compelled to contribute to these problems because they face only a fraction of the total costs of their actions. Thus, in the absence of additional incentives they are typically better off ignoring them to pursue their own individual self-interest. A considerable body of research has therefore developed to better understand the ways in which incentives might be provided to align private interests with those of society (Gordon 1954, Hardin 1968, Ostrom 1990, Grafton et al. 2006). While the specific source of these incentives can vary immensely, recent research highlights two general classes of incentives; namely internalization of economic costs through rights-based or price-based policies, and intrinsic motivation through meaningful participation in rulemaking processes.

Rights-based approaches in fisheries generally include strategies such as individual transferable quotas (ITQ's) and territorial use rights for fishing (TURF's) that provide long-term rights for some actors to use resources, while excluding others. This in turn provides incentives for those who have exclusive access to invest in the long-term sustainability of resources (Grafton et al. 2006, Costello et al. 2008), provided of course that systems are in place to exclude outsiders and prevent overfishing by free-riders (Basurto and Ostrom 2009). Rights-based approaches have, however, also been criticized by some for providing inadequate incentives for the conservation of certain species or areas, while neglecting impacts on the broader ecosystem (Smith et al. 2009, Gibbs 2010, Brewer 2014, Pinkerton 2017). 
Recent insights from research applying a network approach to the study of social-ecological systems has proposed a conceptually simple solution to this problem (Bodin et al. 2014, Bodin et al. 2016). This approach generally begins by identifying the components of ecosystems and uses links to identify situations in which decisions related to one component or resource might have an impact on another. For instance, groups are more likely to sustainably exploit two or more interconnected resources when actors use and are involved in the management of each. More specifically, when actors derive benefits from two or more resources, the use of one or both of which has an impact on the other, then they have at least some economic incentive to invest in strategies to address the broader impacts of their fishing activities. This has led some to recommend diversification of fishing portfolios to foster knowledge and incentives to address the ecosystem impacts of fishing (Berkes et al. 2000, Crona and Bodin 2006, Stoll et al. 2016, Stoll 2017), while also increasing the resilience of fishers to social and environmental change (Kasperski and Holland 2013, Cline et al. 2017). For example, a shrimp fisher that also fishes for crab might be opposed to opening closed areas because they have a more holistic understanding of the relationship between shrimp trawling and crab populations and enjoy some of the economic benefits of that closure while fishing for crab. Furthermore, access to a more diverse portfolio of species may enhance the well-being of fishers by mitigating risks against declines in any individual species.

There is also abundant empirical evidence suggesting that democratic rulemaking can facilitate the management of social dilemmas, contributing to higher levels of cooperation, compliance, and in many cases more sustainable management of resources (Ostrom 1990, Cox et al. 2010, Baggio et al. 2016, Epstein 2017). Although there is some debate about the specific mechanisms linking democratic rulemaking to cooperation (see Abatayo and Lynham 2016), selfdetermination and crowding theory argue that meaningful participation in decision-making processes provides intrinsic motivation for cooperation by satisfying innate psychological goals of self-determination (Deci and Ryan 2000, Frey and Jegen 2001). As a result actors choose to pursue socially beneficial actions and outcomes not because of the potential for economic returns, but rather because they come to personally endorse actions prescribed through participatory decision-making processes (DeCaro and Stokes 2008). Moreover, because participation helps to satisfy psychological goals it has also been suggested that participation may be associated with increased well-being (Ryan and Deci 2000). Indeed, an empirical study of Swiss residents found that citizens with voting rights reported higher levels of subjective wellbeing than foreign residents, while those living in jurisdictions with extended participation rights (i.e. ballot initiatives, public referenda) reported higher levels of well-being than those that lacked such rights (Stutzer and Frey 2006).

\section{Data and Methods}

Data was collected using a dockside survey of shrimp fishers landing and docking in St. Anthony, Newfoundland between August 8 to 19, 2016. Potential respondents were identified and approached by the researchers and a local research assistant at landing points and docks in St. Anthony. Respondents were given the option of completing the paper survey themselves, or to provide oral responses to the questions posed by the researcher or field assistant (see Appendix 2 for survey questions). A total of 52 fishers responded to the survey, 46 of which are included in the analysis as a result of listwise deletion of observations with missing data. The 
final sample included 13 license holders and 33 crew members. A typical shrimp vessel employs four to five crew members (Keenan and Carruthers 2015) and thus license holders are slightly overrepresented in the sample. Finally, the shrimp fishery in SFA 6 is a particularly important source of income for the fishers, more than two thirds of whom earned a majority of their fishing income in this fishery.

Summary statistics are reported in Table 1. Three dependent variables were used in this study: (i) 'oppose', records whether a fisher is strongly or somewhat opposed to opening closed areas to shrimp fishing (1) or not (0), as well as index measures of (ii) the social, and (iii) economic wellbeing of fishers. The concept of well-being has been the subject of considerable theoretical debate in recent years, as scholars highlight opportunities to improve our understanding of material or income-based measures, by emphasizing a more holistic approach that includes relational and subjective well-being (Coulthard et al. 2011, Daw et al. 2011, Hamann et al. 2016). This study adopts a subjective approach by asking respondents to indicate their level of satisfaction with several life domains using a five-point Likert scale, and then aggregates these measures using a principal component analysis of the polychoric correlation matrix. The economic well-being index is comprised of three items that record levels of satisfaction with income, savings, and debt, and explains approximately $71 \%$ of the total variance of the three items (Table S1). The social well-being index, meanwhile, is comprised of five items that record levels of satisfaction with personal health, stress, free time and leisure, relationships with family and friends, and employment, explaining over $82 \%$ of the total variance (Table S2). 
Table 1: Descriptive statistics $(\mathrm{n}=46)$

\begin{tabular}{|c|c|c|c|c|c|}
\hline Variable & Description & Mean & Std. Dev. & Min & Max \\
\hline \multicolumn{6}{|l|}{ Dependent variables } \\
\hline Oppose & $\begin{array}{l}\text { Binary. Respondent is opposed to opening closed areas to } \\
\text { commercial shrimp fishing. }\end{array}$ & 0.196 & 0.401 & 0 & 1 \\
\hline Economic well-being & $\begin{array}{l}\text { Continuous. Index of respondent's level of satisfaction with } \\
\text { income, savings and debt. }\end{array}$ & 0.000 & 0.953 & -2.362 & 2.087 \\
\hline Social well-being & $\begin{array}{l}\text { Continuous. Index of respondent's level of satisfaction with } \\
\text { stress, personal health, relationships, leisure and employment }\end{array}$ & 0.000 & 0.975 & -2.315 & 1.180 \\
\hline \multicolumn{6}{|l|}{ Independent variables } \\
\hline Crab Fisher & Binary. Respondent earned income from crab in the past year & 0.304 & 0.465 & 0 & 1 \\
\hline Species diversification & $\begin{array}{l}\text { Ordinal. Number of species from which fisher earned income } \\
\text { in the past year }\end{array}$ & 1.543 & 0.862 & 1 & 5 \\
\hline Participation & $\begin{array}{l}\text { Binary. Respondent participated in consultations in the past } \\
\text { year }\end{array}$ & 0.152 & 0.363 & 0 & 1 \\
\hline Political efficacy index & $\begin{array}{l}\text { Continuous. Index of respondents perceived influence on } \\
\text { management process }\end{array}$ & 0.000 & 0.921 & -0.476 & 4.859 \\
\hline Dependence & $\begin{array}{l}\text { Ordinal. Fraction of income derived from shrimp fishing in } \\
\text { Area } 6 .\end{array}$ & 2.957 & 0.842 & 1 & 4 \\
\hline License holder & Binary. Respondent owns license for shrimp fishing in Area 6 & 0.283 & 0.455 & 0 & 1 \\
\hline Livelihood diversification & $\begin{array}{l}\text { Binary. Respondent earns income from sources other than } \\
\text { commercial fishing. }\end{array}$ & 0.173 & 0.382 & 0 & 1 \\
\hline Married & Binary. & 0.783 & 0.417 & 0 & 1 \\
\hline Age & Continuous. Age of fisher & 45.630 & 12.776 & 18 & 68 \\
\hline
\end{tabular}


A logistic regression was used to estimate the impacts of species portfolios and democratic rulemaking on the likelihood that a shrimp fisher opposes opening closed areas to shrimp fishing. Crab income records whether a fisher earned any part of their fishing income in the past year from crab, reflecting the hypothesis that fishing portfolios that include interconnected species will affect attitudes towards policies designed to address the ecosystem impacts of fishing. The democratic rulemaking hypothesis, meanwhile, is operationalized using two separate measures. Participation indicates whether a fisher attended consultations in the past year, while political efficacy is a composite measure of three items related to the perceived influence of "people like them", the large offshore fishing fleet, and government scientists on rulemaking in the shrimp fishery. This index explains approximately $63 \%$ of the total variance of the three items (Table S3), and has been used in similar studies seeking to explain collective action and compliance (i.e. Scholz and Lubell 1998). Lower values correspond to a perception that rulemaking in the shrimp fishery is heavily influenced by the perspectives of others; while larger values indicate that higher levels of influence from "people like them". Several additional variables are included to account for potentially intervening factors. For instance, livelihood diversification might influence decisions to pursue additional fishing opportunities, while also reducing the impacts of closures on individual fishers (Allison and Ellis 2001).

Finally, linear regressions are used to estimate the impacts of species portfolio diversification and democratic rulemaking on the social and economic well-being of fishers. Because ecosystem considerations often involve reductions in catches or increases in costs for individual fisheries (for some exceptions see Rice and Duplisea (2014), it is important to consider the impacts of strategies on the welfare of fishers. Ideally, strategies designed to address the ecosystem impacts of fishing would also contribute to the social and economic well-being of individual fishers. Variables included in these models are identical to the attitudes model as we would generally expect a close relationship between well-being and political attitudes towards the closures. The only exception is that species diversification, which measures the number of species from which a fisher has earned income in the past year.

\section{Results}

The results are presented in two sections below. The first section addresses questions concerning the political attitudes of shrimp fishers towards closed areas and the impacts of crab fishing, participation, and political efficacy. These results may be used to inform the development of strategies, such as the promotion of greater participation, devolution of authority, or species portfolio diversification to manage ecosystem trade-offs in fisheries. The second section, meanwhile, continues by considering the potential impacts of species diversification, participation and political efficacy on the subjective social and economic well-being of fishers. More generally this will provide stakeholders and policymakers with a better understanding of the potential livelihood implications of policy change.

\subsection{Political attitudes}

The political attitudes of shrimp fishers towards the selective closures are summarized in Figure 3. It shows that nearly three quarters of the fishers who responded to this survey would support opening these areas to commercial shrimp fishing, while a relatively small number of fishers lacked a clear opinion on the matter. Nonetheless, a non-trivial fraction of shrimp fishers 
$(\sim 19 \%)$ were opposed to opening closed areas, providing a valuable opportunity to explore the hypotheses outlined in section 1.2.

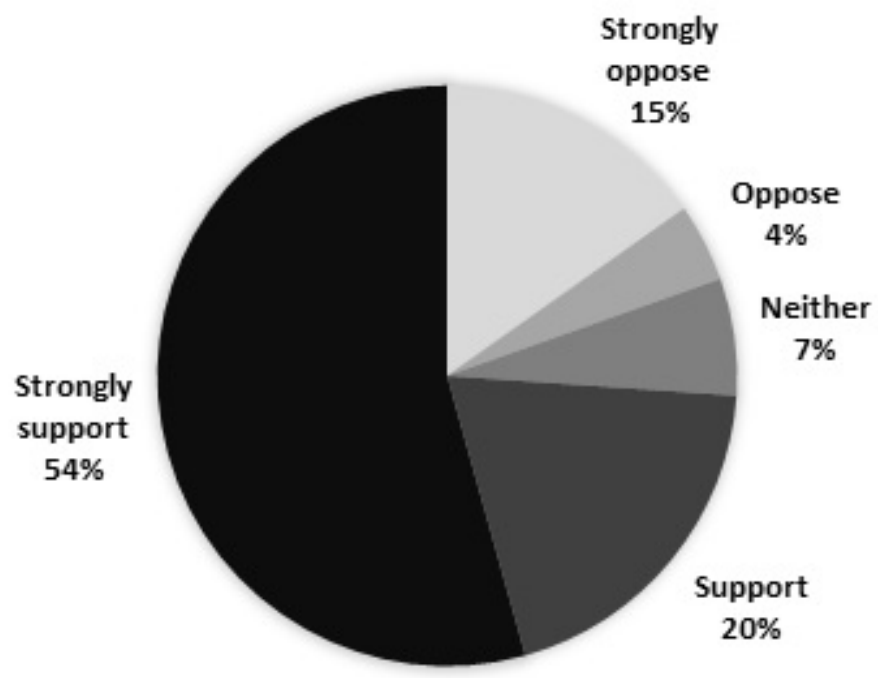

Figure 3: Political attitudes of shrimp fishers towards the opening of closed areas $(n=46)$

Table 2 reports coefficients, standard errors, and confidence intervals, in addition to several scalar model statistics. Model fit was assessed using several measures including a chi-square test, count $\mathrm{R}^{2}$, and by visually analyzing model residuals (Figure $\mathrm{S} 1$ ). Count $\mathrm{R}^{2}$ reports the fraction of observations correctly assigned by the model, showing that the model is successful in classifying over ninety percent of the observations.

Table 2: Logistic Regression Results

\begin{tabular}{llllll}
\hline & Coefficient & Std. Err. & p-value & \multicolumn{2}{l}{$95 \%$ Confidence Interval } \\
\hline Crab income & 7.040 & 1.555 & 0.000 & 3.992 & 10.088 \\
Participation & -2.494 & 1.131 & 0.027 & -4.710 & -0.278 \\
Political efficacy & 1.370 & 0.370 & 0.000 & 0.646 & 2.094 \\
Livelihood diversification & 0.381 & 1.385 & 0.783 & -2.334 & 3.096 \\
Dependence & 0.994 & 0.830 & 0.231 & -0.634 & 2.622 \\
License & 1.535 & 1.594 & 0.335 & -1.588 & 4.659 \\
Married & -0.097 & 1.131 & 0.932 & -2.314 & 2.120 \\
Age & 0.056 & 0.070 & 0.427 & -0.082 & 0.194 \\
Constant & -12.194 & 5.731 & 0.033 & -23.427 & -0.961 \\
\hline N & 46 & & & & \\
Count R & 0.913 & & & & \\
Chi-square & 134.92 & & & & \\
p-value & 0.000 & & & & \\
Mean VIF & 1.42 & & & & \\
Max VIF & 1.79 & & & & \\
\hline
\end{tabular}

Note: Standard errors are clustered by the town in which the fisher lives 
The results suggest that both crab fishing income and political efficacy have a positive and statistically significant impact on the likelihood that a shrimp fisher would be opposed to opening closed areas to shrimp fishing. However, participation was actually associated with a lower likelihood of opposition. Additional models presented in the appendix omit participation (Table S4) and political efficacy (Table S5) because of a general theoretical expectation that they would be closely related (DeCaro and Stokes 2013). However, neither of these changes has an impact on the sign or significance of crab income, participation, or political efficacy coefficients, and in fact there appears to be a limited relationship between participation and the political efficacy of shrimp fishers $(\rho=0.090, p>0.10)$.

Figure 4A plots the probability that a fisher with and without crab fishing income would oppose opening closed areas and reveals substantial differences between the two groups. Whereas the likelihood of opposing the opening of closed areas is approximately 59\% among crab fishers, it is barely above zero for non-crab fishers. Figure 4B, meanwhile, plots the probability that a fisher would oppose opening closed areas as political efficacy varies from its minimum to maximum value. It shows that fishers with higher levels of political efficacy are more likely to oppose opening closed areas to shrimp fishing. None of the remaining factors appear to have a statistically significant impact on the political attitudes of shrimp fishers.

(A)

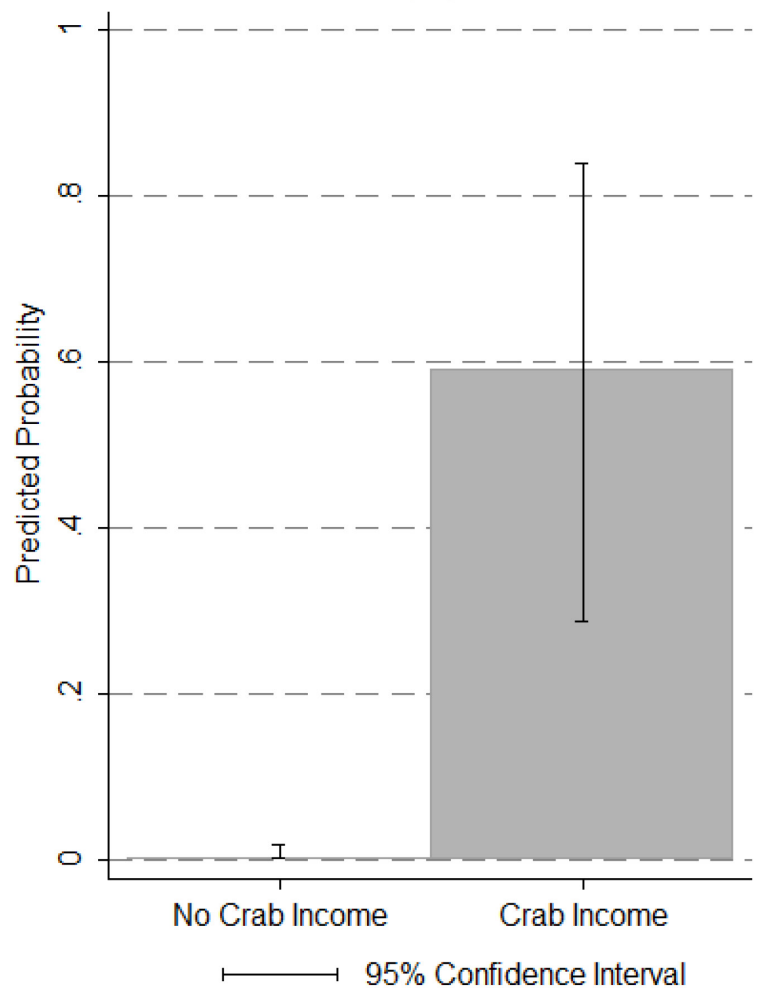

(B)

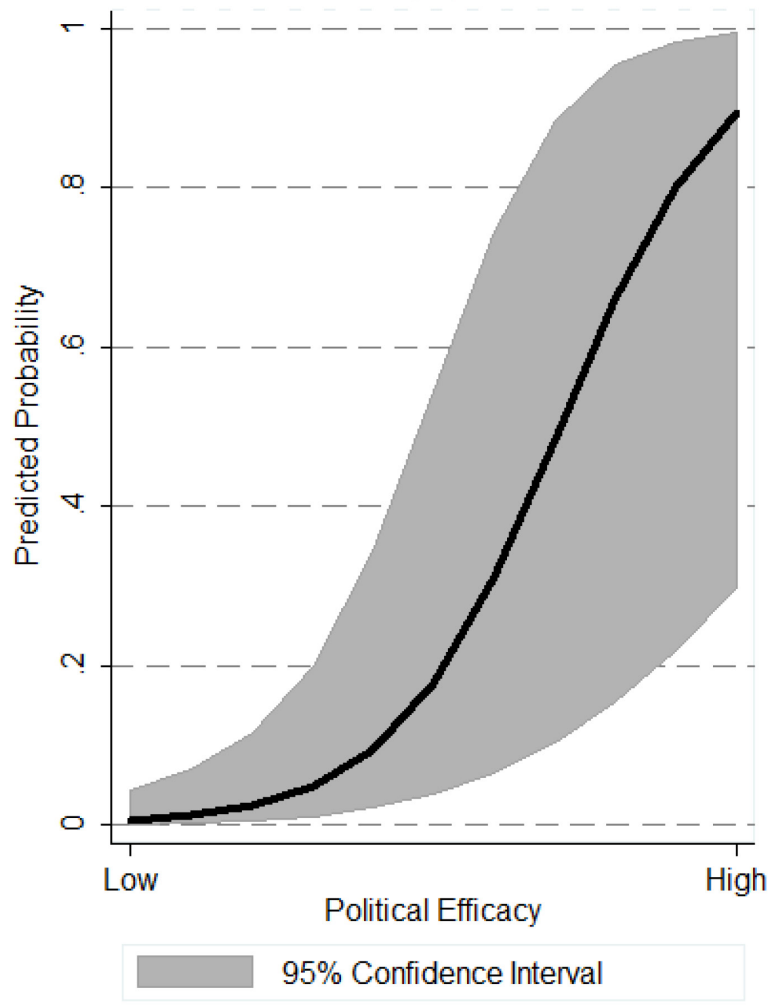

Figure 4: Predicted probability of opposing the opening of closed areas as a function of (A) crab income, and (B) levels of political efficacy. All other values are held at their respective sample means. Confidence intervals calculated using endpoint transformation. 


\subsection{Well-being}

Table 3 and 4 summarize the results of two linear regressions estimating the impact of species diversification, livelihood diversification, and democratic rulemaking on the economic and social well-being of fishers, while controlling for several additional factors. Before turning to the individual hypotheses, it is worth noting that the model performs better in explaining the variation of the economic well-being index. The results suggest that neither participation nor political efficacy have an impact on either outcome. However, fishers that earned income from a more diverse portfolio of species tended to enjoy higher levels of economic well-being $(p<0.01)$, while livelihood diversification was associated with higher levels of social-well-being $(\mathrm{p}<0.10)$. Several fishers expressed personal difficulties with short fishing seasons, which are influenced by several factors including the size of quotas and efficiency of fishing technologies. Thus, diversification outside of fisheries may provide important intangible benefits to fishers, contributing to higher levels of social well-being.

Table 3: Economic well-being

\begin{tabular}{lccccc}
\hline & Coefficient & Std. Err. & p-value & \multicolumn{2}{c}{ 95\% Confidence Interval } \\
\hline Species diversification & 0.512 & 0.161 & 0.007 & 0.168 & 0.857 \\
Livelihood diversification & -0.109 & 0.421 & 0.799 & -1.013 & 0.794 \\
Participation & 0.205 & 0.342 & 0.558 & -0.528 & 0.938 \\
Political efficacy & 0.070 & 0.100 & 0.497 & -0.145 & 0.285 \\
Dependence & -0.327 & 0.128 & 0.023 & -0.601 & -0.053 \\
License & -0.178 & 0.292 & 0.552 & -0.805 & 0.449 \\
Married & -1.057 & 0.369 & 0.013 & -1.850 & -0.265 \\
Age & 0.011 & 0.013 & 0.422 & -0.018 & 0.040 \\
Constant & 0.525 & 0.533 & 0.341 & -0.618 & 1.668 \\
\hline N & 45 & & & & \\
R & 0.427 & & & & \\
Adjusted R & 0.300 & & & & \\
F & 14.00 & & & & \\
p-value & 0.000 & & & & \\
Mean VIF & 1.41 & & & & \\
Max VIF & 1.81 & & & & \\
\hline
\end{tabular}

Note: Standard errors are clustered by the town in which the fisher lives 
Table 4: Social well-being

\begin{tabular}{lccccc}
\hline & Coefficient & Std. Err. & p-value & \multicolumn{2}{c}{$95 \%$ Confidence Interval } \\
\hline Species diversification & 0.286 & 0.273 & 0.313 & -0.299 & 0.871 \\
Livelihood diversification & 0.570 & 0.316 & 0.093 & -0.107 & 1.248 \\
Participation & -0.072 & 0.194 & 0.716 & -0.488 & 0.344 \\
Political efficacy & -0.169 & 0.261 & 0.528 & -0.728 & 0.390 \\
Dependence & -0.172 & 0.248 & 0.499 & -0.704 & 0.360 \\
License & -0.378 & 0.194 & 0.072 & -0.794 & 0.038 \\
Married & -0.777 & 0.228 & 0.004 & -1.267 & -0.288 \\
Age & 0.009 & 0.010 & 0.384 & -0.013 & 0.031 \\
Constant & 0.311 & 0.425 & 0.477 & -0.601 & 1.223 \\
\hline $\mathrm{N}$ & 44 & & & & \\
$\mathrm{R}^{2}$ & 0.205 & & & & \\
Adjusted R & 0.023 & & & & \\
$\mathrm{~F}$ & 21.78 & & & & \\
p-value & 0.000 & & & & \\
Mean VIF & 1.41 & & & & \\
Max VIF & 1.80 & & & \\
\hline
\end{tabular}

Note: Standard errors are clustered by the town in which the fisher lives

\section{Discussion and Conclusion}

The ecological basis for developing and implementing policies to address the ecosystem effects of fishing is clear (Pikitch et al. 2014, Rice and Duplisea 2014). Although important questions remain concerning the science of marine ecosystems, including debates concerning our capacity to reliably predict and manage the ecosystem impacts of fishing (Hilborn 2011); perhaps the most significant challenge (and therefore promise) rests in the development of strategies to address trade-offs (Kellner et al. 2011). More specifically there is abundant empirical evidence to suggest that even well-intentioned and often urgently needed environmental policies are prone to failure if they neglect the human dimensions of resource use (Liu et al. 2007, Charles and Wilson 2008, Bennett and Dearden 2014). Thus, this research which highlights two potential pathways for addressing ecosystem trade-offs in fisheries, namely species portfolio diversification and democratic rulemaking, may inform further developments in the theory and practice of ecosystem-based management, contributing to more sustainable use of marine resources.

Before turning to the implications of this research, it is important to make note of its limitations. First and foremost, the sample which includes 46 individuals does not necessarily reflect the population of 1200 to 1300 affected shrimp fishers. Fishers were selected based upon their presence at the most important landing site for shrimp by weight during the time of research, excluding fishers from other locations and those that had already captured their quota. However, this sample compares favourably to recent published research involving fishers in Newfoundland and Labrador which were able to collect samples of 19 (Kincaid and Rose 2014), and 54 (Foley and Mather 2016), respectively. Second, although there is some evidence to suggest that crab 
fishers have benefited from these closures (Kincaid and Rose 2014; 2017), debates remain as to their impact on the health and abundance of crab. More specifically, several studies have questioned the magnitude and extent of impacts of shrimp trawling on crab (Johnson 2006, Dawe et al. 2007, Mullowney et al. 2014, Nguyen et al. 2014), while others have found that any of the potential benefits for recruitment have been negated by the intensity of crab fishing in these closures (Mullowney et al. 2012). Third and finally, this research which took place during a period of rapid declines in resource conditions may have influenced the perspectives of fishers, contributing to high levels of support for opening closures. In fact, it is possible that the closures themselves were facilitated by the relative abundance of shrimp at the time they were created. Nonetheless, evidence of some, albeit limited ongoing support for closures, and the relationships observed in this study demonstrate that stakeholders may be willing to support policies designed to address ecosystem trade-offs even in a context of crisis and resource decline.

This study suggests that the development and implementation of policies to address trade-offs in fisheries might be facilitated by expanding the species portfolios of fishers, with a particular emphasis on species in which the use of one has an impact on the other. This coincides with theoretical predictions that the use of interlinked resources internalizes the costs and benefits of resource use, contributing to more sustainable use of each (Bodin et al. 2014). These results are also consistent with research suggesting that species portfolio diversification can enhance the well-being of fishers by increasing their resilience to social and environmental change (Kasperski and Holland 2013, Cline et al. 2017). Indeed, although the twentieth century corresponds to a period of increasingly specialized fisheries, there has been a growing chorus of scholars highlighting the broad benefits of diversification, including internalizing costs and benefits, increased resilience to changes in the abundance of resources, and a better understanding of the structure and function of an ecosystem (Bodin et al. 2014, Lindahl et al. 2015, Stoll et al. 2016). While there was unanimous support among survey participants for diversifying species portfolios, questions about access to resources are often highly contentious (Charles 1992, Chuenpagdee and Jentoft 2009), particularly in Newfoundland where rapid shifts in the abundance of species have led to political battles between large-scale and smaller-scale fleets over allocations to changing quotas (Sprout et al. 2016). Thus, the promotion of species diversification to help resolve conflicts between users of different resources may simply engender conflicts over the size and allocation of quotas for the same resource.

Further questions remain as to how economic incentives might be generated in situations where trade-offs arise between conservation goals and resource use, and whether these will have similar impacts on the attitudes and well-being of stakeholders. In this instance, economic incentives were provided by harvesting a resource with well-established markets. However, such markets are typically lacking when it comes to protected areas, and the conservation of forage species for some types of dependent predators, such as seabirds (Cury et al. 2011). Payments for ecosystem services and eco-labelling programs may be relevant in this regard. However, despite their theoretical promise, many have failed to achieve their objectives (Wunder et al. 2008, Muradian et al. 2013) Pecuniary sanctions that punish actors for undesirable behavioural outcomes, rather than rewarding them for desirable ones, is another option that has proved successful in managing conservation trade-offs in some fisheries (Grafton et al. 2006). However, it is unlikely that sanctions would stimulate support from affected stakeholders unless paired with some type of positive economic rewards. 
In addition to species portfolio diversification, the results highlight the possibility of addressing trade-offs by delegating greater authority to stakeholders for rulemaking. This is consistent with several studies that have found relationships between democratic control and the willingness of actors to cooperate to address social dilemmas (Cox et al. 2010, Sutter et al. 2010). However, in this case it is unclear why some fishers feel they have a greater influence on rulemaking than others given the absence of an association between participation and political efficacy. Thus, although this research highlights a potentially useful relationship between political efficacy and support for addressing the impacts of shrimp fishing on crab, more research is needed to investigate why some fishers feel they have a greater influence than others.

The results of this analysis are useful for researchers and policymakers seeking to develop theoretically rigorous and practically useful knowledge to manage ecosystem trade-offs in marine fisheries. There is an urgent need for such knowledge in the context of forage fisheries where increasing dependence on lower trophic level species such as capelin, herring and shrimp (Pauly et al. 1998, Foley et al. 2015) potentially threatens the health and abundance of dependent predators (Cury et al. 2011). Because many dependent predators are also exploited by commercial fisheries it may be possible to address this problem by promoting species diversification through licensing and other mechanisms, potentially also enhancing the resilience of those fishers to social and environmental change (Kasperski and Holland 2013, Cline et al. 2017). Nonetheless, there is a clear need for more research on the human dimensions of ecosystem-based management to help support the pursuit of a more sustainable future for fisheries and the people that depend upon them.

\section{REFERENCES}

Allison, E. H., and F. Ellis. 2001. The livelihoods approach and management of small-scale fisheries. Marine Policy 25:377-388.

Baggio, J., A. Barnett, I. Perez-Ibarra, U. Brady, E. Ratajczyk, N. Rollins, C. Rubiños, H. Shin, D. Yu, and R. Aggarwal. 2016. Explaining success and failure in the commons: the configural nature of Ostrom's institutional design principles. International Journal of the Commons 10.

Basurto, X., and E. Ostrom. 2009. Beyond the Tragedy of the Commons. Economia delle fonti di energia e dell'ambiente 52:35-60.

Bennett, N. J., and P. Dearden. 2014. Why local people do not support conservation: community perceptions of marine protected area livelihood impacts, governance and management in Thailand. Marine Policy 44:107-116.

Berkes, F., J. Colding, and C. Folke. 2000. Rediscovery of traditional ecological knowledge as adaptive management. Ecological Applications 10:1251-1262.

Biedron, I. S., and B. A. Knuth. 2016. Toward shared understandings of ecosystem-based fisheries management among fishery management councils and stakeholders in the US Mid-Atlantic and New England regions. Marine Policy 70:40-48.

Bodin, Ö., B. Crona, M. Thyresson, A.-L. Golz, and M. TengÖ. 2014. Conservation Success as a Function of Good Alignment of Social and Ecological Structures and Processes. Conservation Biology:n/a-n/a. 
Bodin, Ö., G. Robins, R. McAllister, A. Guerrero, B. Crona, M. Tengö, and M. Lubell. 2016. Theorizing benefits and constraints in collaborative environmental governance: a transdisciplinary social-ecological network approach for empirical investigations. Ecology and Society 21.

Botsford, L. W., J. C. Castilla, and C. H. Peterson. 1997. The management of fisheries and marine ecosystems. Science 277:509-515.

Branch, T. A. 2009. How do individual transferable quotas affect marine ecosystems? Fish and Fisheries 10:39-57.

Brewer, J. F. 2014. Hog Daddy and the walls of steel: Catch shares and ecosystem change in the New England groundfishery. Society \& Natural Resources 27:724-741.

Browman, H. I., K. I. Stergiou, T. Agardy, D. Fluharty, M. Hirshfield, P. Livingston, O. Misund, H. Skjoldal, J. Rice, and A. Rosenberg. 2005. Politics and socio-economics of ecosystembased management of marine resources. Marine Ecology Progress Series 300:241-296.

Buchanan, J. M., and W. C. Stubblebine. 1962. Externality. Pages 138-154 Classic Papers in Natural Resource Economics. Springer.

Cavanagh, R. D., S. L. Hill, C. A. Knowland, and S. M. Grant. 2016. Stakeholder perspectives on ecosystem-based management of the Antarctic krill fishery. Marine Policy 68:205211.

Charles, A., and L. Wilson. 2008. Human dimensions of marine protected areas. ICES Journal of Marine Science 66:6-15.

Charles, A. T. 1992. Fishery conflicts: a unified framework. Marine Policy 16:379-393.

Cheung, W. W., and U. R. Sumaila. 2008. Trade-offs between conservation and socio-economic objectives in managing a tropical marine ecosystem. Ecological Economics 66:193-210.

Cheung, W. W., R. Watson, and D. Pauly. 2013. Signature of ocean warming in global fisheries catch. Nature 497:365-368.

Chuenpagdee, R., and S. Jentoft. 2009. Governability Assessment for Fisheries and Coastal Systems: A Reality Check. Human Ecology 37:109-120.

Cline, T. J., D. E. Schindler, and R. Hilborn. 2017. Fisheries portfolio diversification and turnover buffer Alaskan fishing communities from abrupt resource and market changes. Nature Communications 8: 14042.

Cormier, R., C. R. Kelble, M. R. Anderson, J. I. Allen, A. Grehan, and Ó. Gregersen. 2016. Moving from ecosystem-based policy objectives to operational implementation of ecosystem-based management measures. ICES Journal of Marine Science: Journal du Conseil.

Costello, C., S. D. Gaines, and J. Lynham. 2008. Can Catch Shares Prevent Fisheries Collapse? Science 321:1678-1681.

Coulthard, S., D. Johnson, and J. A. McGregor. 2011. Poverty, sustainability and human wellbeing: a social wellbeing approach to the global fisheries crisis. Global Environmental Change 21:453-463.

Cox, M., G. Arnold, and S. Villamayor Tomas. 2010. A Review of Design Principles for Community-Based Natural Resource Management. Ecology and Society 15:38.

Crona, B., and Ö. Bodin. 2006. What you know is who you know? Communication patterns among resource users as a prerequisite for co-management. Ecology and Society 11.

Cury, P. M., I. L. Boyd, S. Bonhommeau, T. Anker-Nilssen, R. J. Crawford, R. W. Furness, J. A. Mills, E. J. Murphy, H. Österblom, and M. Paleczny. 2011. Global seabird response to forage fish depletion — one-third for the birds. Science 334:1703-1706. 
Davies, T. E., G. Epstein, S. E. Aguilera, C. M. Brooks, M. Cox, L. S. Evans, S. M. Maxwell, M. Nenadovic, and N. C. Ban. 2018. Assessing trade-offs in large marine protected areas. PLoS ONE 13:e0195760.

Daw, T., K. Brown, S. Rosendo, and R. Pomeroy. 2011. Applying the ecosystem services concept to poverty alleviation: the need to disaggregate human well-being. Environmental Conservation 38:370-379.

Daw, T., and T. Gray. 2005. Fisheries science and sustainability in international policy: a study of failure in the European Union's Common Fisheries Policy. Marine Policy 29:189-197.

Dawe, E. G., K. D. Gilkinson, S. J. Walsh, W. Hickey, D. R. Mullowney, D. C. Orr, and R. N. Forward. 2007. A study of the effect of trawling in the Newfoundland and Labrador northern shrimp (Pandalus borealis) fishery on mortality and damage to snow crab (Chionoecetes opilio). Can. Tech. Rep. Fish. Aquat. Sci.:43.

DeCaro, D., and M. Stokes. 2008. Social-Psychological Principles of Community-Based Conservation and Conservancy Motivation: Attaining Goals within an AutonomySupportive Environment

Principios Psicológicos Sociales de la Conservación Basada en Comunidades y la Motivación por la Conservación: Alcanzando Metas en un Ambiente de Autonomía y Solidaridad. Conservation Biology 22:1443-1451.

Deci, E. L., and R. M. Ryan. 2000. The "What" and "Why" of Goal Pursuits: Human Needs and the Self-Determination of Behavior. Psychological Inquiry 11:227-268.

DFO, D. o. F. a. O. 2007. Integrated Fisheries Management Plan: Northern Shrimp (SFAs) 0-7 and the Flemish Cap.in D. Department of Fisheries and Oceans, editor.

DFO, D. o. F. a. O. 2016. An assessment of Northern Shrimp (Pandalus borealis) in Shrimp Fishing Areas 4-6 and of Striped Shrimp (Pandalus montagui) in Shrimp Fishing Area 4 in 2015.in D. Department of Fisheries and Oceans, editor., DFO Can.

Sci. Advis. Sec. Sci. Advis. Rep.

Eddy, T. D., H. K. Lotze, E. A. Fulton, M. Coll, C. H. Ainsworth, J. N. Araújo, C. M. Bulman, A. Bundy, V. Christensen, and J. C. Field. 2016. Ecosystem effects of invertebrate fisheries. Fish and Fisheries.

Epstein, G. 2017. Local rulemaking, enforcement and compliance in state-owned forest commons. Ecological Economics 131:312-321.

Fogarty, M. J. 2013. The art of ecosystem-based fishery management. Canadian Journal of Fisheries and Aquatic Sciences 71:479-490.

Foley, P., and C. Mather. 2016. Making Space for Community Use Rights: Insights From "Community Economies" in Newfoundland and Labrador. Society \& Natural Resources:1-16.

Foley, P., and C. Mather. 2018. Ocean grabbing, terraqueous territoriality and social development. Territory, Politics, Governance:1-19.

Foley, P., C. Mather, and B. Neis. 2013. Fisheries allocation policies and regional development: Successes from the Newfoundland and Labrador shrimp fishery. Leslie Harris Centre of Regional Policy and Development, Memorial University.

Foley, P., C. Mather, and B. Neis. 2015. Governing enclosure for coastal communities: Social embeddedness in a Canadian shrimp fishery. Marine Policy 61:390-400.

Frey, B. S., and R. Jegen. 2001. Motivation Crowding Theory. Journal of Economic Surveys 15:589-611. 
Gibbs, M. T. 2010. Why ITQs on target species are inefficient at achieving ecosystem based fisheries management outcomes. Marine Policy 34:708-709.

Gordon, H. S. 1954. The Economic Theory of a Common-Property Resource: The Fishery. Journal of Political Economy 62:124.

Grafton, R. Q., R. Arnason, T. Bjørndal, D. Campbell, H. F. Campbell, C. W. Clark, R. Connor, D. P. Dupont, R. Hannesson, and R. Hilborn. 2006. Incentive-based approaches to sustainable fisheries. Canadian Journal of Fisheries and Aquatic Sciences 63:699-710.

Gutierrez, N. L., R. Hilborn, and O. Defeo. 2011. Leadership, social capital and incentives promote successful fisheries. Nature 470:386-389.

Hamann, M., R. Biggs, and B. Reyers. 2016. An Exploration of Human Well-Being Bundles as Identifiers of Ecosystem Service Use Patterns. PLoS ONE 11:e0163476.

Hardin, G. 1968. The Tragedy of the Commons. Science 162:1243-1248.

Hicks, C. C., N. A. Graham, and J. E. Cinner. 2013. Synergies and tradeoffs in how managers, scientists, and fishers value coral reef ecosystem services. Global Environmental Change 23:1444-1453.

Hilborn, R., J. M. Orensanz, and A. M. Parma. 2005. Institutions, incentives and the future of fisheries. Philosophical Transactions of the Royal Society B: Biological Sciences 360:4757.

Johnson, G. A. 2006. Multispecies interactions in a fishery ecosystem and implications for fisheries management: The impacts of the estuarine shrimp trawl fishery in North Carolina.

Kaiser, M. J., J. S. Collie, S. J. Hall, S. Jennings, and I. R. Poiner. 2002. Modification of marine habitats by trawling activities: prognosis and solutions. Fish and Fisheries 3:114-136.

Kasperski, S., and D. S. Holland. 2013. Income diversification and risk for fishermen. Proceedings of the National Academy of Sciences 110:2076-2081.

Keenan, R., and E. H. Carruthers. 2015. The Northern Shrimp Fishery: The Socio-Economic Importance of Maintaining Adjacency in Allocation Decisions Fish, Food and Allied Workers, St. John's NL.

Kincaid, K., and G. Rose. 2017. Effects of closing bottom trawling on fisheries, biodiversity, and fishing communities in a boreal marine ecosystem: the Hawke Box off Labrador, Canada. Canadian Journal of Fisheries and Aquatic Sciences 74:1490-1502.

Kincaid, K. B., and G. A. Rose. 2014. Why fishers want a closed area in their fishing grounds: Exploring perceptions and attitudes to sustainable fisheries and conservation 10 years post closure in Labrador, Canada. Marine Policy 46:84-90.

Leslie, H. M., and K. L. McLeod. 2007. Confronting the challenges of implementing marine ecosystem-based management. Frontiers in Ecology and the Environment 5:540-548.

Lilly, G., D. Parsons, and D. Kulka. 2000. Was the increase in shrimp biomass on the northeast Newfoundland shelf a consequence of a release in predation pressure from cod? Journal of Northwest Atlantic Fishery Science 27:45-62.

Lindahl, T., Ö. Bodin, and M. Tengö. 2015. Governing complex commons-The role of communication for experimental learning and coordinated management. Ecological Economics 111:111-120.

Link, J. 2010. Ecosystem-based fisheries management: confronting tradeoffs. Cambridge University Press. 
Link, J. S., A. Bundy, W. J. Overholtz, N. Shackell, J. Manderson, D. Duplisea, J. Hare, M. Koen-Alonso, and K. D. Friedland. 2011. Ecosystem - based fisheries management i n the Northwest Atlantic. Fish and Fisheries 12:152-170.

Liu , J., T. Dietz, S. R. Carpenter, M. Alberti, C. Folke, E. Moran, A. N. Pell, P. Deadman, T. Kratz, J. Lubchenco, E. Ostrom, Z. Ouyang, W. Provencher, C. L. Redman, S. H. Schneider, and W. W. Taylor. 2007. Complexity of Coupled Human and Natural Systems. Science 317:1513-1516.

Long, R. D., A. Charles, and R. L. Stephenson. 2015. Key principles of marine ecosystem-based management. Marine Policy 57:53-60.

Long, R. D., A. Charles, and R. L. Stephenson. 2016. Key principles of ecosystem-based management: the fishermen's perspective. Fish and Fisheries.

Martinet, V., and F. Blanchard. 2009. Fishery externalities and biodiversity: Trade-offs between the viability of shrimp trawling and the conservation of Frigatebirds in French Guiana. Ecological Economics 68:2960-2968.

McShane, T. O., P. D. Hirsch, T. C. Trung, A. N. Songorwa, A. Kinzig, B. Monteferri, D. Mutekanga, H. Van Thang, J. L. Dammert, and M. Pulgar-Vidal. 2011. Hard choices: making trade-offs between biodiversity conservation and human well-being. Biological Conservation 144:966-972.

Mullowney, D. R., E. G. Dawe, E. B. Colbourne, and G. A. Rose. 2014. A review of factors contributing to the decline of Newfoundland and Labrador snow crab (Chionoecetes opilio). Reviews in Fish Biology and Fisheries 24:639-657.

Mullowney, D. R. J., C. J. Morris, E. G. Dawe, and K. R. Skanes. 2012. Impacts of a bottom trawling exclusion zone on Snow Crab abundance and fish harvester behavior in the Labrador Sea, Canada. Marine Policy 36:567-575.

Muradian, R., M. Arsel, L. Pellegrini, F. Adaman, B. Aguilar, B. Agarwal, E. Corbera, D. Ezzine de Blas, J. Farley, and G. Froger. 2013. Payments for ecosystem services and the fatal attraction of win-win solutions. Conservati on Letters 6:274-279.

Nguyen, T. X., P. D. Winger, G. Legge, E. G. Dawe, and D. R. Mullowney. 2014. Underwater observations of the behaviour of snow crab (Chionoecetes opilio) encountering a shrimp trawl off northeast Newfoundland. Fisheries Research 156:9-13.

Oceans, D. o. F. a. 2007. Integrated Fisheries Management Plan (IFMP) 2007 Northern Shrimp.in D. o. F. a. Oceans, editor. Government of Canada, Ottawa.

Ommer, R. E., R. I. Perry, G. Murray, and B. Neis. 2012. Social-ecological dynamism, knowledge, and sustainable coastal marine fisheries. Current Opinion in Environmental Sustainability 4:316-322.

Ostrom, E. 1990. Governing the Commons. Cambridge University Press, New York.

Pauly, D., V. Christensen, J. Dalsgaard, R. Froese, and F. Torres. 1998. Fishing down marine food webs. Science 279:860-863.

Phillips, R. A., C. Ridley, K. Reid, P. J. Pugh, G. N. Tuck, and N. Harrison. 2010. Ingestion of fishing gear and entanglements of seabirds: Monitoring and implications for management. Biological Conservation 143:501-512.

Pikitch, E., C. Santora, E. Babcock, A. Bakun, R. Bonfil, D. Conover, P. Dayton, et al., P. Doukakis, D. Fluharty, and B. Heneman. 2004. Ecosystem-based fishery management. Science 305:346-347. 
Pinkerton, E. 2017. Hegemony and resistance: Disturbing patterns and hopeful signs in the impact of neoliberal policies on small-scale fisheries around the world. Marine Policy 80:1-9.

Pitcher, T. J., D. Kalikoski, K. Short, D. Varkey, and G. Pramod. 2009. An evaluation of progress in implementing ecosystem-based management of fisheries in 33 countries. Marine Policy 33:223-232.

Pomeroy, R. S., B. M. Katon, and I. Harkes. 2001. Conditions affecting the success of fisheries co-management: lessons from Asia. Marine Policy 25:197-208.

Pons, M., T. A. Branch, M. C. Melnychuk, O. P. Jensen, J. Brodziak, J. M. Fromentin, S. J. Harley, A. C. Haynie, L. T. Kell, and M. N. Maunder. 2016. Effects of biological, economic and management factors on tuna and billfish stock status. Fish and Fisheries.

Rice, J., and D. Duplisea. 2014. Management of fisheries on forage species: the test-bed for ecosystem approaches to fisheries. ICES Journal of Marine Science: Journal du Conseil 71:143-152.

Ryan, R. M., and E. L. Deci. 2000. Self-determination theory and the facilitation of intrinsic motivation, social development, and well-being. American Psychologist 55:68-78.

Scholz, J. T., and M. Lubell. 1998. Trust and Taxpaying: Testing the Heuristic Approach to Collective Action. American Journal of Political Science 42:398-417.

Smith, T., M. Gibbs, and D. Smith. 2009. Fishing for more effective incentives. Science 323:337-338.

Sprout, P., B. Crann, W. Follett, and T. Taylor. 2016. Report of the Ministerial Advisory Panel: External review of the Department of Fisheries and Oceans' Last-In, First-Out policy (LIFO) for the Northern shrimp fishery.

Stoll, J. S. 2017. Fishing for leadership: The role diversification plays in facilitating change agents. Journal of Environmental Management 199:74-82.

Stoll, J. S., C. M. Beitl, and J. A. Wilson. 2016. How access to Maine's fisheries has changed over a quarter century: The cumulative effects of licensing on resilience. Global Environmental Change 37:79-91.

Stutzer, A., and B. S. Frey. 2006. Political participation and procedural utility: An empirical study. European Journal of Political Research 45:391-418.

Sutter, M., S. Haigner, and M. G. Kocher. 2010. Choosing the Carrot or the Stick? Endogenous Institutional Choice in Social Dilemma Situations. The Review of Economic Studies 77:1540-1566.

Wunder, S., S. Engel, and S. Pagiola. 2008. Taking stock: A comparative analysis of payments for environmental services programs in developed and developing countries. Ecological Economics 65:834-852.

WWF, W. W. F. 2016. Food for all: small fish with big influence. Toronto. 